\title{
The study of the phase composition of the products of electrochemical oxidation of sulfide granules of the system $\mathrm{Cu}_{1.96} \mathrm{~S}-\mathrm{Ni}_{3} \mathrm{~S}_{2}-\mathrm{Cu}-\mathrm{Ni}$
}

\author{
C) Olga V. Nechvoglod, ${ }^{*+}$ and Alena G. Upolovnikova \\ Institute of Metallurgy UB RAS. Amundsen St., 101. \\ Ekaterinburg, 620016. Russia.E-mail:pcmlab@mail.ru
}

\begin{abstract}
*Supervising author; ${ }^{+}$Corresponding author Keywords: copper sulfide, nickel sulfide, sulfur, phase composition, electrochemical oxidation, electrolysis, non-stoichiometric sulfides.
\end{abstract}

\begin{abstract}
The crystallization rate of copper and nickel sulfides influences on the phase formation processes. The high crystallization rate (about $10^{3}$ degrees/s), achieved through granulation of the sulfide copper-nickel melt, leads to the stabilization of non-stoichiometric phases, the formation of ultrafine structures, which are grains and partial dissolution of the metal component in the sulfide. The structure of the granules is formed by nickel sulfide $\left(\mathrm{Cu}_{1.96} \mathrm{~S}\right)$ phases in the form of dendritic inclusions of $2-20 \mu \mathrm{m}$ in size in the nickel sulfide phase $\left(\mathrm{Ni}_{3} \mathrm{~S}_{2}\right)$. According to the phase diagram of the state of $\mathrm{Cu}-\mathrm{Ni}-\mathrm{S}$, a solid solution of $\mathrm{Cu}-\mathrm{Ni}$ may be present in the composition of eutectic compounds with copper and nickel sulphides.

The electrochemical oxidation of copper and nickel sulfides in a solution of sulfuric acid occurs through a series of successive phase transformations described in the work, during which the conversion of sulfides occurs in intermediate oxidation states oxidizing to the elemental state: $\mathrm{Cu}_{1.96} \mathrm{~S} \rightarrow \mathrm{Cu}_{1.8} \mathrm{~S} \rightarrow \mathrm{Cu}_{1.75} \mathrm{~S} \rightarrow \mathrm{CuS}$ $\rightarrow \mathrm{S} ; \mathrm{Ni}_{3} \mathrm{~S}_{2} \rightarrow \mathrm{NiS} \rightarrow \mathrm{S}$. The non-stoichiometric_composition of compounds suggests the presence of excessive or deficient sulfur and metal contents in the crystal lattice, which can affect the mechanism and sequence of phase transformations during the electrochemical oxidation of sulfide granules. Dissolution occurs not only on the surface of the granules, but also along the grain boundaries. The leached areas form capillaries inside the granules, through which electrolyte enters the electrochemical reactions. Porous sulfur sulfide sludge forms on the surface of the granules. The phase composition of the sludge was studied. The main phase components of poorly soluble products are nickel granules $\mathrm{Ni}_{3+\mathrm{x}} \mathrm{S}_{2}-\mathrm{Cu}_{2-\mathrm{x}} \mathrm{S}$.
\end{abstract}

\section{References}

[1] V.A. Chanturia. Wigderhaus V.E. Electrochemistry of sulfides. Theory and practice of flotation. Moscow: Publishing House "Ore and Metals". 2008. 272p. (russian)

[2] O.V. Nechvoglod, E.N. Selivanov, S.V. Mamyachenkov. The electrolysis of granulated copper-nickel matte. Fray International Symposium. Metals and materials Processing in Clean Environment. Aqueous, Low Temperatures and Electrochemical Processing (Cancun, 27 Nov. - 1 Dec., 2011): Wilmington, FLOGEN Technologies Inc. 2012. Vol.6. P.601-620.

[3] D.M. Chizhikov, Z.F. Gulyanitskaya, L.V. Pliginskaya, E.A. Subbotina. Electrometallurgy of coppernickel sulfide alloys in aqueous solutions. Moscow: Science. 1977. 205p. (russian)

[4] I.A. Kakovsky, S.S. Naboychenko. Kinetics of oxidation and dissolution of non-ferrous metal chalcogenides. Moscow: Science. 1986. (russian)

[5] I.G. Fokeeva, L.B. Tsymbulov, L.N. Yertseva et al. Choice of the optimal cooling regime for a Feinstein with a high copper content. Non-ferrous metals. 2005. No.7. P.42-45. (russian)

[6] L.Yu. Udoeva, E.N. Selivanov, A.L. Kozhanov et al. The structure of granular copper-nickel matte. Nonferrous metals. 2008. No.10. P.41-43. (russian)

[7] M.I. Travnichek, I.N. Maslyanitsky. Changing the structure of copper-nickel matte depending on the mode of their cooling. University News. Non-ferrous metallurgy. 1970. No.1. P.31-34. (russian)

[8] L.Yu. Udoeva, N.I. Selmensky, O.V. Nechvoglod, E.N. Selivanov. The influence of the cooling mode of the melt of high-copper Feinstein on its structure. Sat tr conf. The structure and properties of metal and slag melts. Yekaterinburg: Ural Branch of the Russian Academy of Sciences. 2008. Vol.3. P.121-124. (russian) 
[9] O.V. Nechvoglod, and E.N. Selivanov. The masstransfer during electrochemical oxidation of coppernickel sulfide alloy granules. Butlerov Communications. 2016. Vol.47. No.8. P.80-86. DOI: 10.37952/ROI-jbc-01/16-47-8-80

[10] O.V. Nechvoglod, E.N. Selivanov, S.V. Mamyachenkov. Effect of Structure on the Electrochemical Oxidation Rate of Copper and Nickel Sulfides. Defect and Diffusion Forum. 2012. Vol.326-328. P.383-387.

[11] D.C. Price, W.G. Davenport. Anodic reactions of $\mathrm{Ni}_{3} \mathrm{~S}_{2}, \beta-\mathrm{NiS}$ and nickel matte. Journal of Applied Electrochemistry. 1982. Vol.12. P.281-290.

[12] H.R. Watling. The bioleaching of nickel-copper sulfides. Hydrometallurgy. 2006. Vol.91. Iss.1-4. P.70-88.

[13] E.N. Selivanov, O.V. Nechvoglod, L.Yu. Udoeva, V.G. Lobanov, S.V. Mamyachenkov. Electrochemical oxidation of copper-nickel sulfide-metal alloys. University News. Non-ferrous metallurgy. 2009. No.6. P.15-20. (russian)

[14] E.N. Selivanov, O.V. Nechvoglod, L.Yu. Udoeva, S.V. Mamyachenkov, V.A. Sergeev. Electrochemical oxidation of nickel sulfide-metal alloys. University News. Non-ferrous metallurgy. 2010. No.2. P.20-25. (russian) 